\title{
IMPLEMENTASI ALGORITMA K-MEDOIDS UNTUK KLASTERISASI DATA PENYAKIT PASIEN DI RSUD KOTA BANDUNG
}

\author{
Asri Dwi Andini ${ }^{1}$, Toni Arifin ${ }^{2}$ \\ 1 Universitas Adhirajasa Reswara Sanjaya \\ e-mail: asridwiandini98@gmail.com \\ 2Universitas Adhirajasa Reswara Sanjaya \\ e-mail: toni.arifin@ars.ac.id
}

\begin{abstract}
Abstrak
Penyakit adalah suatu keadaan abnormal dimana tubuh ataupun pikiran mengalami ketidaknyamanan atau disfungsi terhadap orang yang dipengaruhinya. Setiap harinya jumlah pasien di rumah sakit selalu bertambah dengan jenis penyakit yang berbeda. Tumpukan data penyakit pasien yang berada pada rumah sakit pun hanya sebatas memberikan laporan jumlah pasien yang berobat dengan penyakit yang diderita. Oleh sebab itu, perlu adanya pengelompokan untuk membantu pihak rumah sakit menemukan informasi mengenai penyakit yang paling banyak diderita oleh pasien. Pada penelitian ini dilakukan pengelompokkan data penyakit pasien menggunakan teknik data mining clustering dengan menggunakan algoritma $\mathrm{K}$ Medoids. K-Medoids merupakan salah satu metode clustering yang berfungsi untuk memecah dataset menjadi kelompok-kelompok dan mampu mengatasi kelemahan dari metode K-Means yang sensitive terhadap outlier. Hasil dari penelitian ini menunjukkan bahwa penggunaan 3 cluster menjadi jumlah cluster terbaik dengan nilai Silhouette Coefficient sebesar 0,409373. Dari pengujian yang dilakukan didapatkan hasil clustering yaitu cluster 0 sebanyak 18 data yang didominasi oleh penyakit yang berada pada klinik gawat darurat, lalu pada cluster 1 sebanyak 2 data yang didominasi oleh penyakit pada klinik kemuning dan klinik gawat darurat, sedangkan pada cluster 2 sebanyak 197 data yang didominasi oleh penyakit pada klinik rehab medik sebanyak 20 data.
\end{abstract}

Kata Kunci: Clustering, K-Medoids, Silhouette Coefficient, Penyakit Pasien

\begin{abstract}
Disease is an abnormal condition which is the body or mind experiences discomfort or dysfunction of the person affected. Every day the number of patients in the hospital always increases with different types of diseases. Piles of patient disease data at the hospital were only providing reports of disease suffered by patients. Therefore, grouping is required to help the hospital find information about the most common disease suffered by patients. In this study grouping patient disease data using data mining clustering techniques with the K-Medoids algorithm. K-Medoids is a clustering method that functions to break the dataset into groups and able to overcome the weaknesses of the K-Means method which is sensitive to outliers. The results of this study indicate that the use of 3 clusters is the best number of clusters with a Silhouette Coefficient of 0.409373 . From the tests conducted, the results of clustering are cluster 0, 18 data are dominated by diseases in emergency clinics, in cluster 1 there are 2 data that are dominated by diseases in kemuning clinics and emergency clinics, whereas in cluster 2 there are 197 data which is dominated by diseases in medical rehab clinic as much as 20 data.
\end{abstract}

Keywords: Clustering, K-Medoids, Silhouette Coefficient, Patient Disease

Naskah diterima 20 April 2020; direvisi 04 Mei 2020; diterbitkan 31 Agustus 2020 


\section{Pendahuluan}

Penyakit adalah suatu keadaan abnormal dimana tubuh ataupun pikiran mengalami ketidaknyamanan atau disfungsi terhadap orang yang dipengaruhinya (Juninda et al., 2019). Lingkungan dan pola hidup sehat dapat menjadi pengaruh besar dalam penyakit yang diderita pasien. Setiap harinya jumlah pasien di rumah sakit selalu bertambah dengan jenis penyakit yang berbeda. Pihak rumah sakit pun selalu dituntut untuk memperbarui data pasien yang dikumpulkan dari data penyakit pasien yang telah selesai melakukan perawatan maupun masih dalam tahap perawatan. Hal tersebut menyebabkan bertumpuknya data penyakit pasien di rumah sakit.

Dari data penyakit pasien tersebut, pihak rumah sakit membutuhkan pengolahan data penyakit lebih lanjut untuk menemukan informasi mengenai penyakit yang paling banyak diderita oleh pasien. Dengan mengetahui kondisi ini, pihak rumah sakit dapat mengambil tindakan kebijakan dalam antisipasi pengobatan dan pencegahan penyakit salah satunya yaitu dengan melakukan penyuluhan atau sosialisasi sehingga kegiatan tersebut akan tepat sasaran terhadap penyakit yang sering diderita pada masyarakat (Sundari \& Ariani, 2019). Selain itu, pengolahan data penyakit ini dapat dijadikan sebagai bahan evaluasi pihak rumah sakit dalam merencanakan pembangunan fasilitas baru, penambahan tenaga medis spesialis ataupun penambahan jenis obat. Oleh karena itu, dibutuhkan suatu teknik ataupun metode untuk mengolah data penyakit pasien tersebut.

Data mining adalah metode dimana data yang telah didapatkan akan diolah untuk mengetahui pola dari data sehingga dapat di ambil informasi yang tersembunyi dari data tersebut (Triyanto, 2015). Salah satu teknik analisa Data Mining adalah clustering yang mana konsep dasar dari clustering adalah mengelompokkan sejumlah objek ke dalam cluster dimana cluster yang baik adalah cluster yang memiliki tingkat kesamaan yang tinggi antar objek di dalam suatu cluster dan tingkat ketidaksamaan yang tinggi dengan objek cluster yang lainnya (Silitonga \& Sri, 2017).

Algoritma yang digunakan pada teknik clustering ini adalah Algoritma $K$ Medoids yang didasarkan pada penelitian terdahulu yang dilakukan oleh (Juninda et al., 2019) mengenai Penerapan Algoritma K-Medoids untuk Pengelompokan Penyakit di Pekanbaru Riau. Berdasarkan penelitiannya menunjukan bahwa algoritma K-Medoids dapat melakukan pengelompokan penyakit yang ada di Pekanbaru Riau dengan baik. Algoritma $K-$ Medoids juga merupakan metode yang diciptakan untuk mengatasi kelemahan algoritma $K$-Means yang sensitif terhadap outlier, karena nilai yang sangat besar dapat secara substansial mendistorsi distribusi data (Asmiatun et al., 2020).

\section{Metode Penelitian}

\subsection{Perancangan Penelitian}

Menurut Dawson dalam (Amrin et al., 2019) terdapat empat metode penelitian yang umum digunakan diantaranya penelitian langsung, eksperimen, studi kasus dan survey. Pada tahapan penelitian ini, penelitian yang digunakan adalah penelitian eksperimen. Adapun tahapannya dapat dilihat pada Gambar 1.

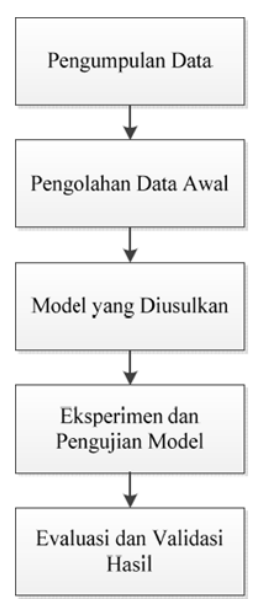

Gambar 1. Tahapan Penelitian

\subsection{Pengumpulan Data}

Pada penelitian ini dataset yang digunakan adalah dataset publik yang mana data tersebut mudah diperoleh dan tersedia untuk umum yang dapat diteliti oleh siapapun. Dataset yang digunakan pada penelitian ini adalah data penyakit pasien di RSUD Kota bandung pada tahun 2019 yang diambil dari situs http://data.bandung.go.id.

\subsection{Pengolahan Data Awal}

Pada tahap ini dilakukan tahap pembersihan data (cleaning data) yang mana menghilangkan nilai-nilai yang salah atau kosong, memperbaiki dan memeriksa data yang tidak konsisten. Selanjutnya dilakukan transfromasi data pada Microsoft Excel yang 
nantinya data tersebut dapat langsung diolah dengan model yang telah ditentukan.

\section{A. Data Cleaning}

Sebelum melakukan proses data mining perlu melakukan proses cleaning data terlebih dahulu. Proses cleaning meliputi membuang duplikasi data, memeriksa data yang inkonsisten dan memperbaiki kesalahan pada data seperti kesalahan penulisan. Atribut data yang tidak digunakan adalah tahun dan bulan yang nantinya akan dihilangkan sehingga atribut yang digunakan berjumlah 5 atribut yaitu Kode ICD, Nama Penyakit, Kamar, Laki-Laki, dan Perempuan.

\section{B. Data Transformasi}

Tahap transformasi adalah tahapan mengubah format data asli menjadi bentuk yang sesuai untuk mempermudah proses penambangan data. Data yang berjenis nominal seperti kamar harus dilakukan proses inisialisasi data terlebih dahulu ke dalam bentuk angka atau numerikal. Untuk melakukan inisialisasi dapat dilakukan dengan cara pengurutan angka berdasarkan frekuensinya. Pengubahan ini dilakukan pada Micorosoft Excel. Tabel atribut yang telah diinisialisasi dapat dilihat pada Tabel 1 . Tabel 1. Data Transformasi

\begin{tabular}{|l|c|c|}
\hline \multicolumn{1}{|l|}{ Kamar } & Frekuensi & Inisialisasi \\
\hline Klinik Rehab Medik & 22 & 1 \\
\hline Klinik Kandungan & 21 & 2 \\
\hline Klinik Dalam & 20 & 3 \\
\hline Gawat Darurat & 19 & 4 \\
\hline Klinik Anak & 16 & 5 \\
\hline Klinik Syaraf & 15 & 6 \\
\hline Klinik Bedah & 12 & 7 \\
\hline Klinik Gigi & 12 & 8 \\
\hline Klinik Kulit Kelamin & 12 & 9 \\
\hline Klinik Mata & 12 & 10 \\
\hline Klinik Orthopedic & 11 & 11 \\
\hline Klinik THT & 11 & 12 \\
\hline Klinik Bedah Anak & 6 & 13 \\
\hline Klinik Psikiatri & 5 & 14 \\
\hline Klinik Bedah Mulut & 4 & 15 \\
\hline
\end{tabular}

\begin{tabular}{|l|c|c|}
\hline Klinik Kemuning & 4 & 16 \\
\hline Klinik Urologi & 4 & 17 \\
\hline Klinik Dahlia & 3 & 18 \\
\hline Klinik Akupuntur & 2 & 19 \\
\hline $\begin{array}{l}\text { Klinik Bedah } \\
\text { Syaraf }\end{array}$ & 2 & 20 \\
\hline $\begin{array}{l}\text { Klinik Konservasi } \\
\text { Gigi }\end{array}$ & 2 & 21 \\
\hline Klinik vct & 2 & 22 \\
\hline
\end{tabular}

\section{Populasi dan Sample Penelitian}

Populasi dataset pada penelitian ini sebanyak 473 data dengan jumlah 7 atribut. Sebelum dilakukan pengambilan sample, terlebih dahulu dilakukan proses pembersihan data. Besarnya sample pada penelitian ini berdasarkan pada rumus slovin yaitu:

$$
n=\frac{N}{N(d)^{2}+1}
$$

dimana :

$\mathrm{n}=$ Sample

$\mathrm{N}=$ Populasi

$\mathrm{d}=$ Nilai presisi $95 \%$ atau sig. $=0,05$ (tingkat kesalahan yang dikehendaki adalah 5\%)

Berdasarkan rumus diatas, maka perhitungan sample sebagai berikut:

$$
\begin{aligned}
n=\frac{473}{473(0.05)^{2}+1} & \\
n=\frac{473}{2.1825} \rightarrow n & =216,72394 \\
& =217 \text { (dibulatkan) }
\end{aligned}
$$

Teknik pengambilan sample penelitian ini menggunakan Simple Random Sampling dimana penarikan sample menggunakan prosedur yang memungkinkan setiap elemen dalam populasi akan memiliki peluang sama untuk dijadikan sample. Sample diambil secara acak tanpa memperhatikan tingkatan yang ada dalam populasi (Muningsih \& Kiswati, 2015).

\subsection{Model yang diusulkan}

Pada tahap ini ditentukan model yang akan digunakan dalam penelitian. Model atau metode yang diusulkan dalam penelitian ini adalah algoritma K- Medoids. Model yang diusulkan ditunjukkan dengan flowchart pada Gambar 2. 


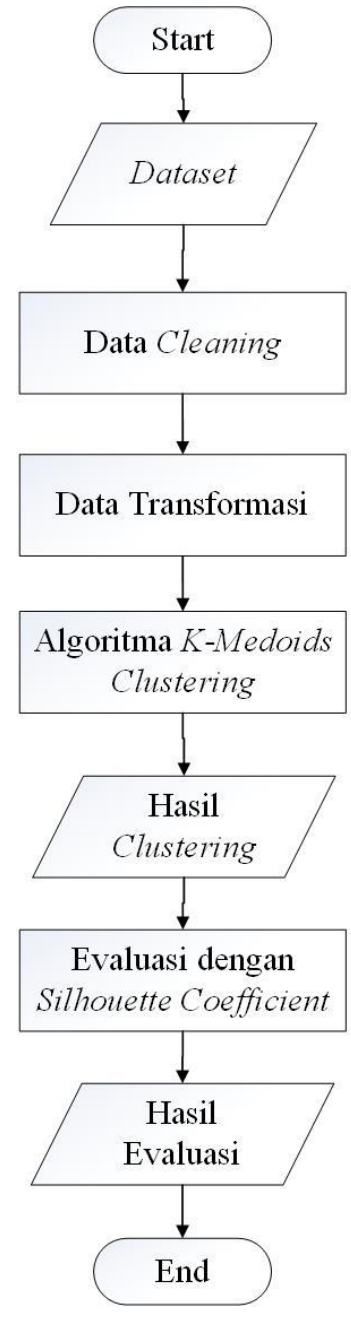

Gambar 2. Model Yang Diusulkan

\subsection{Eksperimen dan pengujian model}

Pada tahap ini dilakukan pengujian terhadap model yang diusulkan untuk mendapatkan hasil kinerja dari model yang diusulkan. Dataset yang telah siap diolah akan diuji dengan menggunakan algoritma $K$ medoids seperti pada Gambar 3.

\subsection{Evaluasi dan validasi model}

Pada tahap ini dilakukan evaluasi terhadap eksperimen dan pengujian pada model yang diusulkan sehingga dapat mengetahui hasil kinerja dalam penelitian ini. Evaluasi hasil clustering dilakukan dengan menggunakan Silhouette Coefficient.

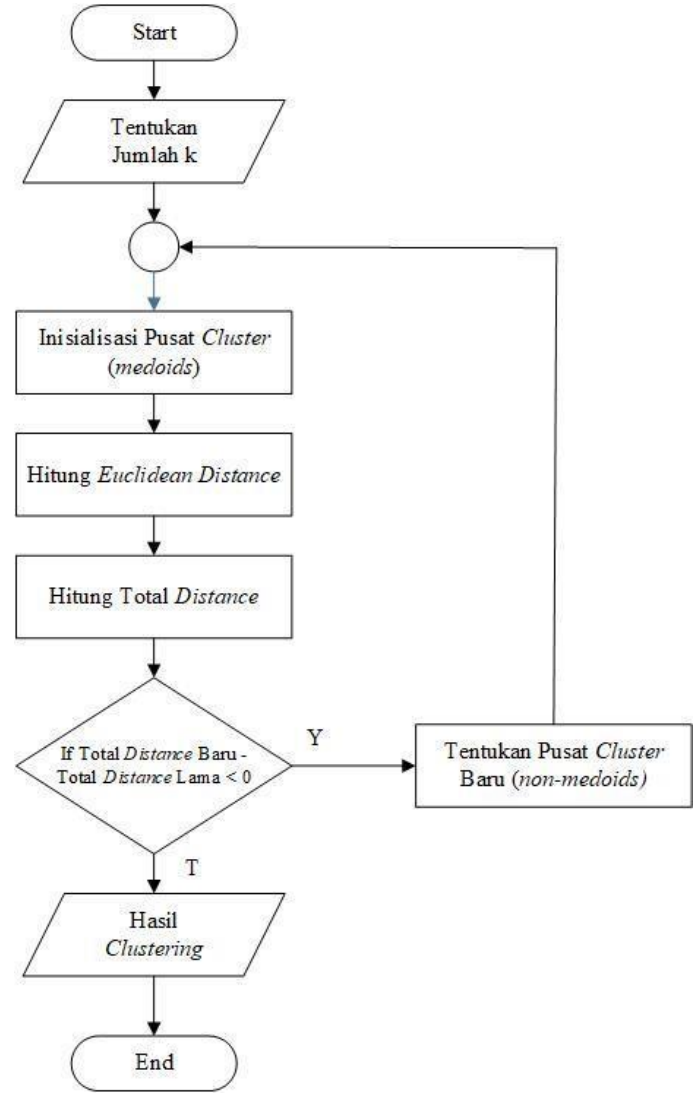

Gambar 3. Flowchart Algoritma K-Medoids

\section{Hasil dan Pembahasan}

3.1. Perhitungan Manual Algoritma KMedoids

Dalam penelitian ini dilakukan perhitungan manual algoritma K-Medoids dengan menggunakan Microsoft Excel. Adapun langkah-langkah perhitungan algoritma $K$-Medoids adalah sebagai berikut: 1. Inisialisasi pusat cluster sebanyak $k$ (jumlah cluster)

Dalam penelitian ini, dibentuk 3 cluster berdasarkan kamar, jumlah pasien laki-laki dan jumlah pasien perempuan. Selanjutnya adalah menentukan titik pusat dari setiap cluster (medoids) yang dipilih secara random dari data yang telah di transformasi. Berikut merupakan medoids awal yang digunakan:

Tabel 2. Medoids Awal

\begin{tabular}{|c|c|c|c|}
\hline Cluster & Kamar & Laki-laki & Perempuan \\
\hline 0 & 16 & 3449 & 661 \\
\hline 1 & 4 & 1022 & 1263 \\
\hline 2 & 3 & 756 & 1241 \\
\hline
\end{tabular}




\section{Hitung setiap objek ke cluster terdekat menggunakan persamaan ukuran jarak Euclidean Distance}

Setelah menentukan medoids awal, hitung jarak setiap data ke masing-masing medoids menggunakan rumus Euclidean Distance sehingga diperoleh hasil penghitungan jarak setiap data untuk masing-masing cluster. Berikut merupakan contoh perhitungan pada data pertama:

Data pertama ke pusat cluster 0 :

$d\left(x_{1} c_{0}\right)$

$=\sqrt{(5-16)^{2}+(89-3449)^{2}+(73-661)^{2}}$

$=\sqrt{(-11)^{2}+(-3360)^{2}+(-588)^{2}}$

$=\sqrt{(121)+(11289600)+(345744)}$

$=\sqrt{11635465}$

$=3411,08$

Data pertama ke pusat cluster 1 :

$d\left(x_{1} c_{1}\right)$

$=\sqrt{(5-4)^{2}+(89-1022)^{2}+(73-1263)^{2}}$

$=\sqrt{(1)^{2}+(-933)^{2}+(-1190)^{2}}$

$=\sqrt{(1)+(870489)+(1416100)}$

$=\sqrt{2286590}$

$=1512,15$

Data pertama ke pusat cluster 2:

$d\left(x_{1} c_{2}\right)$

$=\sqrt{(5-3)^{2}+(89-756)^{2}+(73-1241)^{2}}$

$=\sqrt{(2)^{2}+(-667)^{2}+(-1168)^{2}}$

$=\sqrt{(4)+(444889)+(1364224)}$

$=\sqrt{1809117}$

$=1345,0342$

Perhitungan tersebut dilakukan pada semua data yang mana terdapat 217 dataset penyakit pasien. Setelah dilakukan perhitungan pada semua data, maka proses selanjutnya adalah memilah cluster mana dari tiap data dimana nilai terkecil dari tiap perhitungan cluster akan menjadi penentu cluster yang akan diikuti dari data tersebut. Hasil perhitungan jarak pada iterasi-1 dapat dilihat pada Tabel 4.

3. Inisialisasikan pusat cluster baru secara acak pada masing - masing objek sebagai kandidat non medoids

Setelah didapatkan hasil jarak dari setiap objek pada iterasi ke-1, maka dilanjutkan ke perhitungan iterasi ke-2. Pada tahap ini, tentukan kembali medoids baru (non medoids) yang dapat dilihat pada tabel berikut:
Tabel 3. Medoids Kedua

\begin{tabular}{|c|c|c|c|}
\hline Cluster & Kamar & Laki-laki & Perempuan \\
\hline 0 & 2 & 0 & 861 \\
\hline 1 & 4 & 3619 & 3616 \\
\hline 2 & 10 & 149 & 179 \\
\hline
\end{tabular}

Tabel 4. Hasil Perhitungan Iterasi-1

\begin{tabular}{|c|c|c|c|c|c|c|}
\hline$\frac{\text { Kode }}{\text { ICD }}$ & Nama Penyakit & co & C1 & C2 & $\begin{array}{l}\text { Jarak } \\
\text { Minimum }\end{array}$ & $\begin{array}{c}\text { Cluster } \\
\text { Yang } \\
\text { Diikuti }\end{array}$ \\
\hline A01.0 & Typhoid fever & 3411,08 & 1512,147 & 1345,0342 & 1345,0342 & 2 \\
\hline A02.0 & Salmonella enteritis & 3500,929 & 1607,28 & 1435,3738 & 1435,3738 & 2 \\
\hline A09 & $\begin{array}{l}\text { Diarrhoea and } \\
\text { gastroenteritis of }\end{array}$ & 2500,575 & 0 & 266,9100 & 0 & 1 \\
\hline A09 & $\begin{array}{l}\text { Diarrhoea and } \\
\text { gastroenteritis of }\end{array}$ & 3189,438 & 1298,578 & 1150,4090 & 1150,4090 & 2 \\
\hline A15.9 & $\begin{array}{l}\text { Respiratory tuberculosis } \\
\text { unspecified, }\end{array}$ & 3347,726 & 1412,904 & 1244,6887 & 1244,6887 & 2 \\
\hline A16.2 & $\begin{array}{l}\text { Tuberculosis of lung, } \\
\text { without mention of }\end{array}$ & 3264,88 & 1339,201 & 1178,9185 & 1178,9185 & 2 \\
\hline A16.9 & $\begin{array}{l}\text { Respiratory tuberculosis } \\
\text { unspecified, without }\end{array}$ & 3371,243 & 1477,837 & 1314,2910 & 1314,2910 & 2 \\
\hline$\ldots+\cdots \cdots \cdots$ & ..................... & 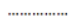 & $\ldots+\cdots \cdots \cdots$ & $\ldots \ldots \ldots \ldots$ & 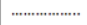 & 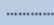 \\
\hline$z 96.1$ & $\begin{array}{l}\text { Presence of intraocular } \\
\text { lens }\end{array}$ & 3335,02 & 1391,84 & 1223,25 & 1223,25 & 2 \\
\hline
\end{tabular}

4. Hitung jarak setiap objek yang berada pada masing - masing cluster dengan kandidat non medoids

Hitung jarak setiap data ke masingmasing non medoids menggunakan rumus Euclidean Distance sehingga diperoleh hasil penghitungan jarak setiap data untuk masing-masing cluster. Berikut merupakan contoh perhitungan pada data pertama:

$d\left(x_{1} c_{0}\right)$

$$
\begin{aligned}
&=\sqrt{(5-2)^{2}+(89-0)^{2}+(73-861)^{2}} \\
&=\sqrt{(3)^{2}+(89)^{2}+(-788)^{2}} \\
&=\sqrt{(9)+(7921)+(620944)} \\
&=\sqrt{628874} \\
&=793,016
\end{aligned}
$$

Data pertama ke pusat cluster 1 :

$$
\begin{aligned}
& d\left(x_{1} c_{1}\right) \\
& \begin{aligned}
=\sqrt{(5-4)^{2}+(89-3619)^{2}+(73-3616)^{2}} \\
=\sqrt{(1)^{2}+(-3530)^{2}+(-3543)^{2}} \\
=\sqrt{(1)+(12460900)+(12552849)} \\
=\sqrt{25013750} \\
=5001,37
\end{aligned}
\end{aligned}
$$

Data pertama ke pusat cluster 2:

$$
d\left(x_{1} c_{2}\right)
$$

$$
\begin{aligned}
=\sqrt{(5-10)^{2}+(89-149)^{2}+(73-179)^{2}} \\
=\sqrt{(-5)^{2}+(-60)^{2}+(-106)^{2}} \\
=\sqrt{(25)+(3600)+(11236)} \\
=\sqrt{14861} \\
=121,906
\end{aligned}
$$

Perhitungan tersebut dilakukan pada semua data yang mana terdapat 217 dataset 
penyakit pasien. Setelah dilakukan perhitungan pada semua data, maka proses selanjutnya adalah memilah cluster mana dari tiap data dimana nilai terkecil dari tiap perhitungan cluster akan menjadi penentu cluster yang akan diikuti dari data tersebut. Hasil perhitungan jarak pada iterasi-1 dapat dilihat pada Tabel 5.

Tabel 5. Hasil Perhitungan Iterasi-2

\begin{tabular}{|c|c|c|c|c|c|c|}
\hline $\begin{array}{l}\text { Kode } \\
\text { ICD }\end{array}$ & Nama Penyakit & co & c1 & c2 & $\begin{array}{l}\text { Jarak } \\
\text { Minimum }\end{array}$ & $\begin{array}{c}\text { Cluster } \\
\text { Yang } \\
\text { Diikuti }\end{array}$ \\
\hline \begin{tabular}{|l|} 
A01.0 \\
\end{tabular} & Typhoid fever & \begin{tabular}{|l|}
793,016 \\
\end{tabular} & 5001,37 & 121,906 & 121,906 & 2 \\
\hline A02.0 & Salmonella enteritis & 845,1538 & 5098,967 & 215,6061 & 215,6061 & 2 \\
\hline A09 & $\begin{array}{l}\text { Diarrhoea and } \\
\text { gastroenteritis of }\end{array}$ & 1098,222 & 3504,428 & 1391,841 & 1098,222 & 0 \\
\hline A09 & $\begin{array}{l}\text { Diarthoea and } \\
\text { gastroenteritis of }\end{array}$ & 735,7377 & 4775,669 & 146,3045 & 146,3045 & 2 \\
\hline A15.9 & $\begin{array}{l}\text { Respiratory tuberculosis } \\
\text { unspecified, }\end{array}$ & 714,6489 & 4904,522 & 22,58318 & 22,58318 & 2 \\
\hline A16.2 & $\begin{array}{l}\text { Tuberculosis of lung, } \\
\text { without mention of }\end{array}$ & 703,6292 & 4826,031 & 70,39176 & 70,39176 & 2 \\
\hline A16.9 & $\begin{array}{l}\text { Respiratory tuberculosis } \\
\text { unspecified, without }\end{array}$ & 784,3558 & 4964,666 & 94,72592 & 94,72592 & 2 \\
\hline$\ldots \ldots \ldots$ & 군. & $\cdots$ & $\cdots \cdots \cdots$ & …….... & $\cdots \cdots \cdots \cdots$ & …….. \\
\hline 296.1 & $\begin{array}{l}\text { Presence of intraocular } \\
\text { lens }\end{array}$ & 698,133 & 4884,05 & 0 & 0 & 2 \\
\hline
\end{tabular}

5. Hitung total simpangan (S) dengan menghitung total cost baru - total cost lama

Setelah didapatkan hasil nilai jarak pada iterasi ke-1 dan iterasi ke-2, hitung total simpangan (S) dengan mencari selisih dari total cost baru dan total cost lama.

$\mathrm{S}=$ total cost baru - total cost lama

$$
=1286918-1315466
$$$$
=-28547,9
$$

Dikarenakan total simpangan $<0$, maka perhitungan dilanjutkan sampai dengan total simpangan $>0$. Tahap selanjutnya tentukan kembali medoids baru sebagai titik pusat cluster pada iterasi ke-3, berikut merupakan medoids yang digunakan:

Tabel 6. Medoids Ketiga

\begin{tabular}{|c|c|c|c|}
\hline Cluster & Kamar & Laki-laki & Perempuan \\
\hline 0 & 6 & 1578 & 1651 \\
\hline 1 & 4 & 1203 & 2173 \\
\hline 2 & 18 & 987 & 1549 \\
\hline
\end{tabular}

Hitung kembali jarak setiap data ke masing-masing non medoids menggunakan rumus Euclidean Distance sehingga diperoleh hasil penghitungan jarak setiap data untuk masing-masing cluster. Berikut merupakan contoh perhitungan pada data pertama:

Data pertama ke pusat cluster 0:

$d\left(x_{1} c_{0}\right)$

$=\sqrt{(5-6)^{2}+(89-1578)^{2}+(73-1651)^{2}}$

$$
\begin{aligned}
& =\sqrt{(-1)^{2}+(1489)^{2}+(-1578)^{2}} \\
& =\sqrt{(1)+(2217121)+(2490084)} \\
& =\sqrt{4707206} \\
& =2169,61
\end{aligned}
$$

Data pertama ke pusat cluster 1:

$d\left(x_{1} c_{1}\right)$

$$
\begin{aligned}
=\sqrt{(5-} & 4)^{2}+(89-1203)^{2}+(73-2173)^{2} \\
& =\sqrt{(1)^{2}+(-1114)^{2}+(-2100)^{2}} \\
& =\sqrt{(1)+(1240996)+(4410000)} \\
& =\sqrt{5650997} \\
& =2377,18
\end{aligned}
$$

Data pertama ke pusat cluster 2:

$$
\begin{aligned}
& d\left(x_{1} c_{2}\right) \\
& =\sqrt{(5-18)^{2}+(89-987)^{2}+(73-1549)^{2}} \\
& =\sqrt{(-13)^{2}+(-898)^{2}+(-1476)^{2}} \\
& =\sqrt{(169)+(806404)+(2178576)} \\
& =\sqrt{2985149} \\
& =1727,76
\end{aligned}
$$

\begin{tabular}{|c|c|c|c|c|c|c|}
\hline$\frac{\text { Kode }}{\text { ICD }}$ & Nama Penyakit & co & C1 & C2 & $\begin{array}{l}\text { Jarak } \\
\text { Minimum }\end{array}$ & $\begin{array}{c}\text { Cluster } \\
\text { Yang } \\
\text { Diikuti }\end{array}$ \\
\hline A01.0 & Typhoid fever & 2169,61 & 2377,183 & 1727,758 & 1727,758374 & 2 \\
\hline A02.0 & Salmonella enteritis & 2266,765 & 2465,931 & 1818,938 & 1818,937602 & 2 \\
\hline A09 & $\begin{array}{l}\text { Diarrhoea and } \\
\text { gastroenteritis of }\end{array}$ & 678 & 927,826 & 288,4736 & 288,473569 & 2 \\
\hline A09 & $\begin{array}{l}\text { Diarrhoea and } \\
\text { gastroenteritis of }\end{array}$ & 1946,635 & 2183,726 & 1527,769 & 1527,768634 & 2 \\
\hline A15.9 & $\begin{array}{l}\text { Respiratorytuberculosis } \\
\text { unspecified, }\end{array}$ & 2072,151 & 2276,898 & 1627,467 & 1627,467358 & 2 \\
\hline A16.2 & $\begin{array}{l}\text { Tuberculosis of lung, } \\
\text { without mention of }\end{array}$ & 1994,563 & 2212,371 & 1559,801 & 1559,800949 & 2 \\
\hline A16.9 & $\begin{array}{l}\text { Respiratory tuberculosis } \\
\text { unspecified, without }\end{array}$ & 2133,424 & 2347,163 & 1696,235 & 1696,234948 & 2 \\
\hline A17.0 & Tuberculous meningitis & 2098,774 & 2313,963 & 1662,538 & 1662,538421 & 2 \\
\hline$\cdots \cdots \cdots$ & 근 & $\cdots \cdots \cdots \cdots$ & $\ldots \ldots \ldots$ & $\ldots \ldots \ldots \ldots$ & $\ldots \ldots \ldots \ldots$ & 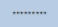 \\
\hline $\mathrm{Z} 96.1$ & $\begin{array}{l}\text { Presence of intraocular } \\
\text { lens }\end{array}$ & 2051,546 & 2255,435 & 1605,991 & 1605,991283 & 2 \\
\hline
\end{tabular}

Perhitungan tersebut dilakukan pada semua data yang mana terdapat 217 dataset penyakit pasien. Setelah dilakukan perhitungan pada semua data, maka proses selanjutnya adalah memilah cluster mana dari tiap data dimana nilai terkecil dari tiap perhitungan cluster akan menjadi penentu cluster yang akan diikuti dari data tersebut. Hasil perhitungan jarak pada iterasi-1 dapat dilihat pada Tabel 7 .

Tabel 7. Hasil Perhitungan Iterasi-3

Setelah dilakukan perhitungan jarak pada iterasi ke-3, hitung kembali total simpangan baru dengan mencari selisih total cost baru dengan total cost lama.

$\mathrm{S}=$ total cost baru - total cost lama 


$$
=12195953-1286918
$$$$
=9034,99
$$

Dikarenakan total simpangan $>0$, maka perhitungan dihentikan sehingga didapatkan hasil cluster akhir sebagai berikut:

Tabel 8. Hasil Cluster Akhir

\begin{tabular}{|c|c|c|c|c|c|}
\hline $\begin{array}{l}\text { Kode } \\
\text { ICD }\end{array}$ & Nama Penyakit & Kamar & Laki-laki & Perempuan & Cluster \\
\hline A01.0 & Typhoid fever & 5 & 89 & 73 & 2 \\
\hline A02.0 & Salmonella enteritis & 16 & 8 & 16 & 2 \\
\hline A09 & $\begin{array}{l}\text { Diarrhoea and } \\
\text { gastroenteritis of }\end{array}$ & 4 & 1022 & 1263 & 0 \\
\hline A09 & $\begin{array}{l}\text { Diarrhoea and } \\
\text { gastroenteritis of }\end{array}$ & 5 & 295 & 187 & 2 \\
\hline A15.9 & $\begin{array}{l}\text { Respiratory tuberculosis } \\
\text { unspecified, }\end{array}$ & 3 & 139 & 160 & 2 \\
\hline A16.2 & $\begin{array}{l}\text { Tuberculosis of lung, } \\
\text { without mention of }\end{array}$ & 5 & 218 & 192 & 2 \\
\hline ............. & 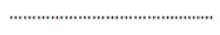 & ................... & $\ldots \ldots \ldots \ldots . . . .$. & ………......... & ........... \\
\hline$Z 96.1$ & $\begin{array}{l}\text { Presence of intraocular } \\
\text { lens }\end{array}$ & 10 & 149 & 179 & 2 \\
\hline
\end{tabular}
manual dengan algoritma K-Medoids yang telah dilakukan, didapatkan hasil cluster akhir dengan nilai $k=3$ yaitu cluster 0 sebanyak 18 items, cluster 1 sebanyak 2 items, dan cluster 2 sebanyak 197 items sehingga total keseluruhan adalah 217 items.

\subsection{Perhitungan Algoritma K-Medoids dengan Rapidminer}

Pada tahap ini pemodelan dilakukan dengan menggunakan Rapidminer versi 9.6 dengan langkah sebagai berikut:

1. Pilih read excel lalu drag ke panel process kemudian Import Data Excel pada panel parameters dengan klik excel file kemudian pilih file excel yang akan diuji.

2. Pada panel operators ketik K-Medoids lalu drag ke panel process dan tentukan jumlah $\mathrm{k}$ yang akan digunakan.

3. Pada panel process hubungkan connector pada masing-masing process lalu klik tombol Run untuk melihat hasil clustering.

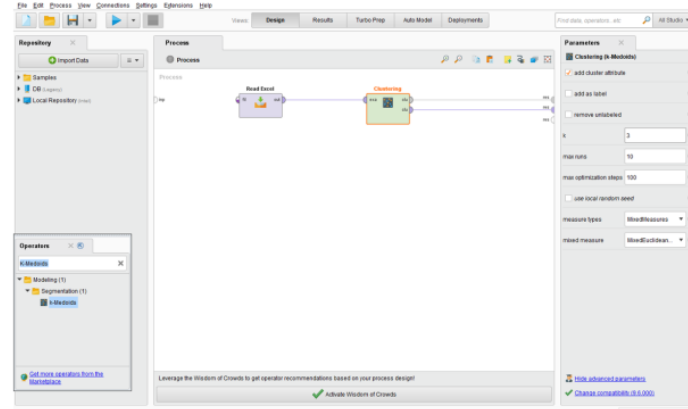

Gambar 4. Tampilan Proses Clustering

4. Setelah proses running selesai maka akan tampil hasil clustering dan cluster model yang dihasilkan dari dataset dan metode yang dipilih.

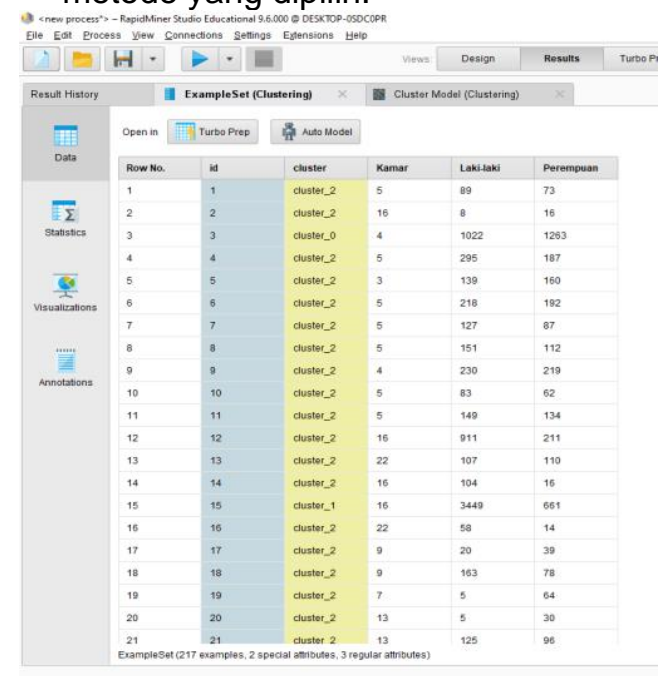

Gambar 5. Tampilan Hasil Cluster (III) <new process* > - RapidMiner Studio Educational 9.6.000 @ DESKTOP-OSDCOPR File Edit Process View Connections Settings Extensions Help
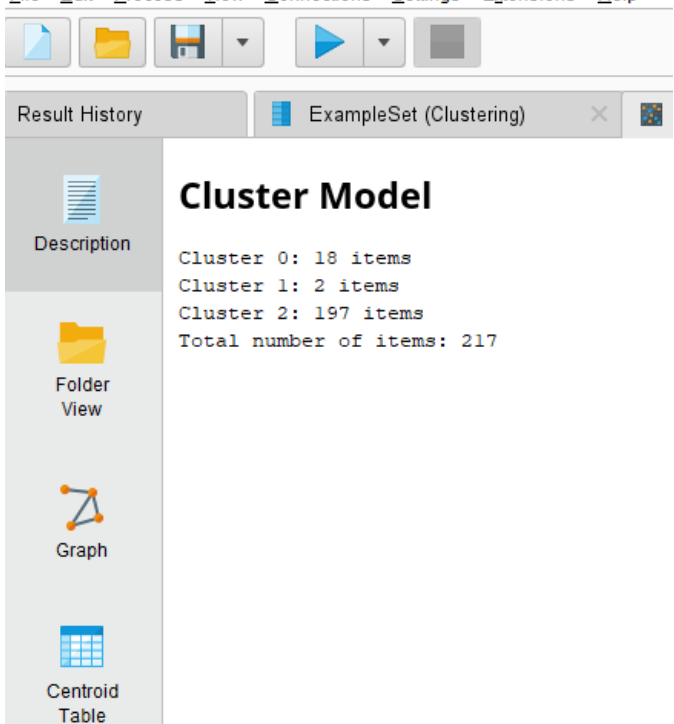

Gambar 6. Tampilan Cluster Model 
Berdasarkan hasil pengujian dataset sebanyak 217 data dengan menggunakan software rapidminer 9.6, pada cluster model yang dibentuk dengan 3 cluster diperoleh hasil cluster 0 sebanyak 18 items, cluster 1 sebanyak 2 items dan cluster 2 sebanyak 197 items dengan total keseluruhan 217 items.

\subsection{Evaluasi Hasil Cluster}

Dari hasil pengujian dataset yang telah dilakukan, maka tahap selanjutnya adalah mengevaluasi hasil cluster untuk menentukan kualitas hasil cluster tersebut. Pada tahap ini evaluasi hasil clustering yang digunakan adalah Metode Silhouette Coefficient. Adapun langkah-langkah perhitungan Silhouette Coefficient adalah sebagai berikut:

1. Hitung jarak rata-rata dari suatu objek misalkan objek ke-i dengan semua objek lain yang berada di dalam satu cluster

Pada tahap ini hitung nilai average dissimilarity atau a(i). Berikut merupakan contoh perhitungan jarak Data ke-1 terhadap semua data yang berada pada cluster yang sama yaitu cluster 2 :

$$
\begin{aligned}
& a(i)=\sqrt{\begin{array}{l}
(121,9057-121,9057)^{2}+(215,606-121,9057)^{2}+(146,304-121,9057)^{2}+ \\
(22,58318-121,9057)^{2}+(70,3917-121,9057)^{2}+(94,72592-121,9057)^{2}+ \\
(67,21607-121,9057)^{2}+(90,53729-121,9057)^{2}+\cdots+(0-121,9057)^{2}
\end{array}} \\
& a(i)=\frac{306449,4}{197} \\
& a(i)=1555,581
\end{aligned}
$$

2. Hitung rata-rata jarak dari objek ke-i tersebut dengan semua objek pada cluster lainnya, kemudian ambillah nilai terkecilnya.

Pada tahap ini hitung lowest average dissimilarity atau $b(i)$. Berikut merupakan contoh perhitungan jarak data pertama terhadap semua data yang berada pada cluster 0 dan 1 kemudian cari nilai ratarata jarak yang paling kecil.

- Jarak data pertama pada cluster 2 ke cluster 0:

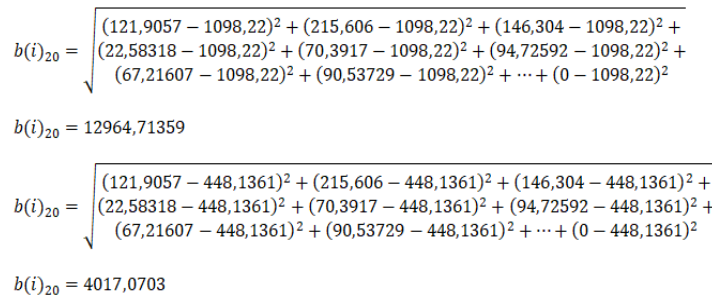

Hitung perhitungan diatas pada semua data yang berada pada cluster 0 sehingga diperoleh:

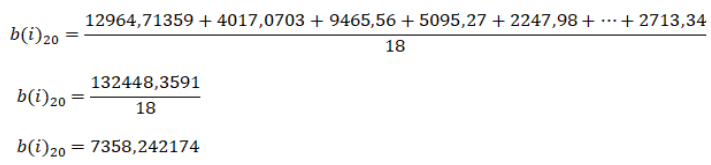

- Jarak data pertama pada cluster 2 ke cluster 1 :

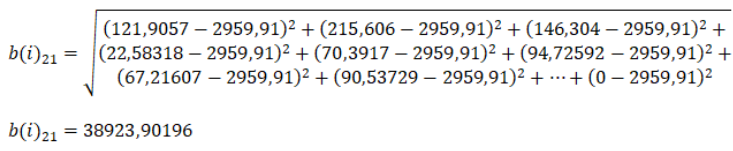

Hitung perhitungan diatas pada semua data yang berada pada cluster 1 sehingga diperoleh:

$$
\begin{aligned}
b(i)_{21} & =\frac{38923,90196+2713,343918}{2} \\
b(i)_{21} & =\frac{41637,24587}{2} \\
b(i)_{21} & =20818,62294
\end{aligned}
$$

Dari perhitungan kedua cluster diatas, ambil nilai minimum diantara kedua cluster tersebut.

$b(i)=(7358,242174<20818,62294)$

$b(i)=7358,242174$

\section{Hitung nilai silhouette coefficient}

Setelah mengetahui nilai $a(i)$ dan $b(i)$, hitung nilai silhouette coefficient. Berikut merupakan hasil perhitungan nilai silhouette coefficient pada cluster 2 :

$$
\begin{aligned}
& s(i)=1-\frac{a(i)}{b(i)} \\
& s(i)=1-\frac{1555,581}{7358,242174} \\
& s(i)=0,78859
\end{aligned}
$$

Lakukan perhitungan diatas pada semua cluster. Berikut adalah hasil perhitungan nilai silhouette coefficient pada semua cluster:

Tabel 9. Nilai Silhouette Coefficient

\begin{tabular}{|c|c|}
\hline Cluster & Nilai Silhouette Coefficient \\
\hline 0 & 0,034497 \\
\hline 1 & 0,405027 \\
\hline 2 & 0,788593 \\
\hline
\end{tabular}

Setelah didapatkan nilai silhouette coefficient, hitung nilai silhouette coefficient global dengan menghitung rata-rata nilai 
silhouette coefficient pada semua cluster sebagai berikut:

$$
\begin{aligned}
& s(i)=\frac{0,034497+0,405027+0,788593}{3} \\
& s(i)=\frac{1,228118}{3} \\
& s(i)=0,409373
\end{aligned}
$$

Untuk mengetahui apakah hasil validasi cluster yang dibentuk tergolong dalam kategori baik, maka dilakukan percobaan validasi dari pembentukan jumlah $k$ sebanyak 2 sampai dengan 5 k (cluster). Berikut adalah tabel hasil percobaan validasi cluster dengan menggunakan silhouette coefficient:

Tabel 10. Hasil Pengujian Silhouette Coefficient

\begin{tabular}{|c|c|c|}
\hline $\begin{array}{c}\text { Data } \\
\text { Uji }\end{array}$ & $\begin{array}{c}\text { Nilai k } \\
\text { (Jumlah } \\
\text { Cluster) }\end{array}$ & $\begin{array}{c}\text { Rata-Rata } \\
\text { Silhouette } \\
\text { Coefficient }\end{array}$ \\
\hline \multirow{4}{*}{217} & 2 & 0,346969 \\
\cline { 2 - 3 } & 3 & 0,409373 \\
\cline { 2 - 3 } & 4 & 0,138031 \\
\cline { 2 - 3 } & 5 & 0,025724 \\
\hline
\end{tabular}

Berdasarkan hasil evaluasi cluster yang telah dilakukan, kualitas cluster dengan jumlah cluster sama dengan 3 memiliki kualitas yang paling baik karena nilai silhouette coefficient dengan $k=3$ merupakan nilai yang paling mendekati 1 yaitu sebesar 0,409373 sehingga pembentukan 3 cluster telah menghasilkan pengelompokan yang baik.

\subsection{Rekapitulasi Hasil Cluster}

Berdasarkan hasil dari proses clustering dengan algoritma K-Medoids menggunakan aplikasi rapidminer maupun perhitungan secara manual, maka dihasilkan informasi sebagai berikut:

Tabel 11. Rekapitulasi Cluster 0, 1, 2

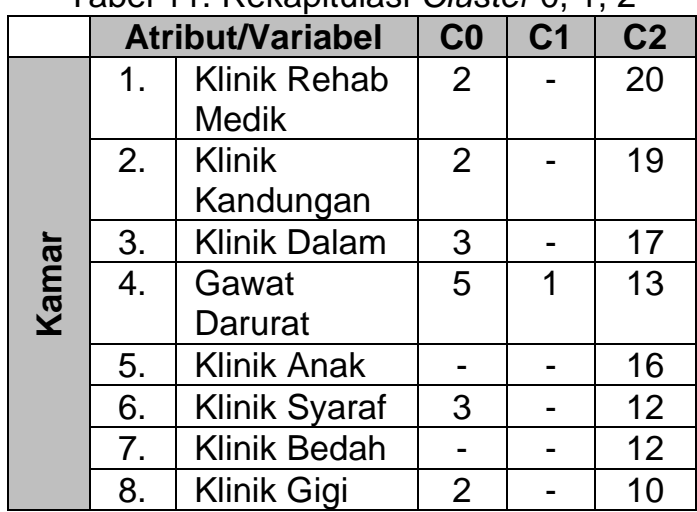

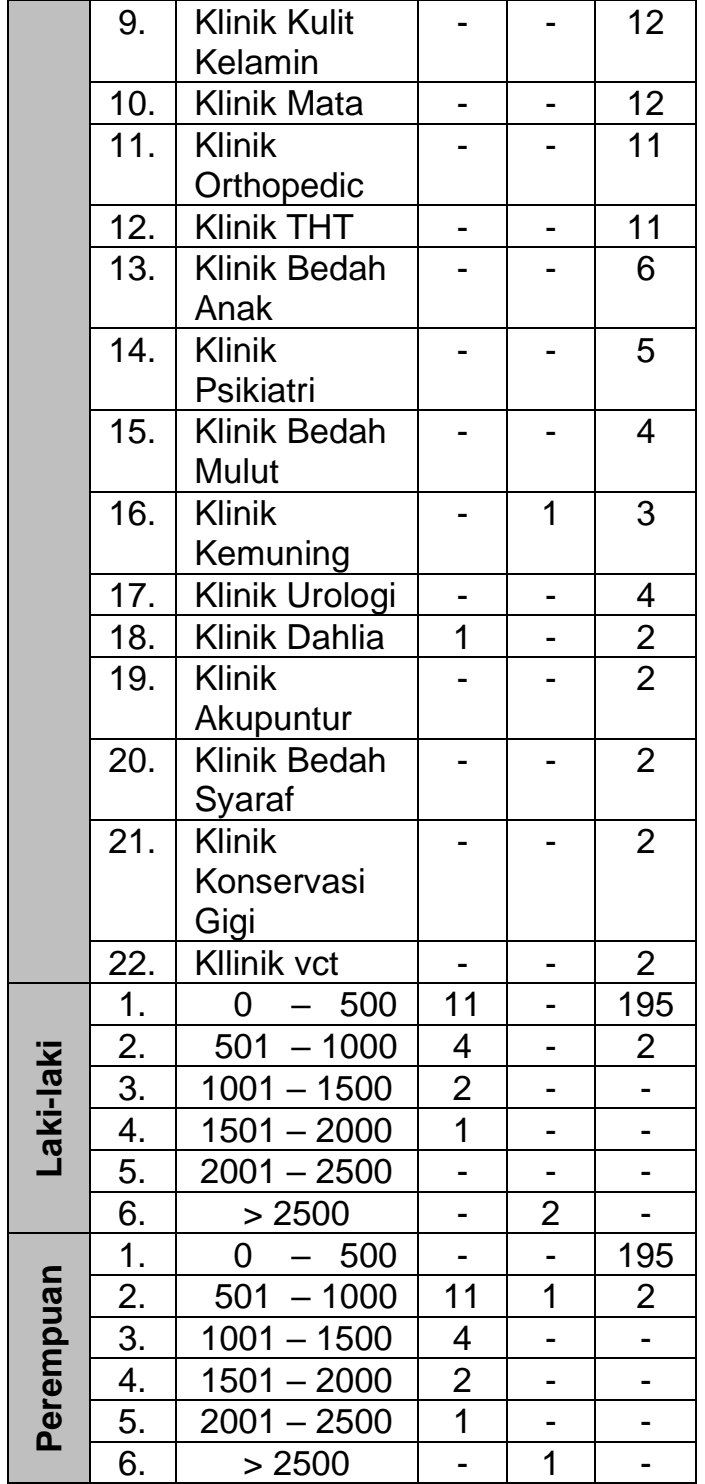

Berdasarkan tabel diatas maka dapat disimpulkan bahwa klinik gawat darurat mendominasi pada cluster 0 sebanyak 5 data, lalu pada cluster 1 hanya terdapat 2 data yang diisi oleh klinik kemuning dan klinik gawat darurat, sedangkan pada cluster 2 didominasi oleh klinik rehab medik sebanyak 20 data. Untuk lebih lengkapnya, informasi yang didapatkan dapat dilihat pada Tabel 12 . di bawah ini: 
Tabel 12. Kesimpulan

\begin{tabular}{|c|c|}
\hline Cluster & Kesimpulan \\
\hline 0 & 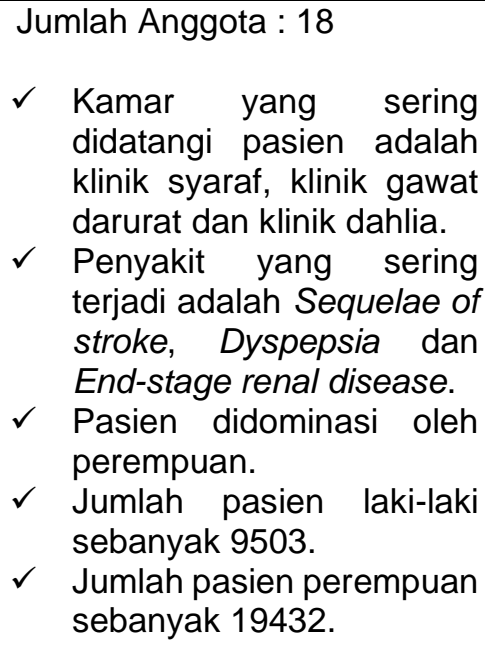 \\
\hline 1 & $\begin{array}{l}\text { Jumlah Anggota : } 2 \\
\checkmark \quad \text { Kamar yang sering } \\
\text { didatangi pasien adalah } \\
\text { klinik gawat darurat dan } \\
\text { klinik kemuning. } \\
\checkmark \quad \text { Penyakit yang sering } \\
\text { terjadi adalah Fever dan } \\
\text { HIV disease resulting in } \\
\text { unspecified infectious or } \\
\text { parasitic disease. } \\
\checkmark \quad \text { Pasien didominasi oleh } \\
\text { laki-laki. } \\
\checkmark \quad \begin{array}{l}\text { Jumlah pasien laki-laki } \\
\text { sebanyak } 7068 .\end{array} \\
\checkmark \\
\text { Jumlah pasien perempuan } \\
\text { sebanyak } 4277 .\end{array}$ \\
\hline 2 & 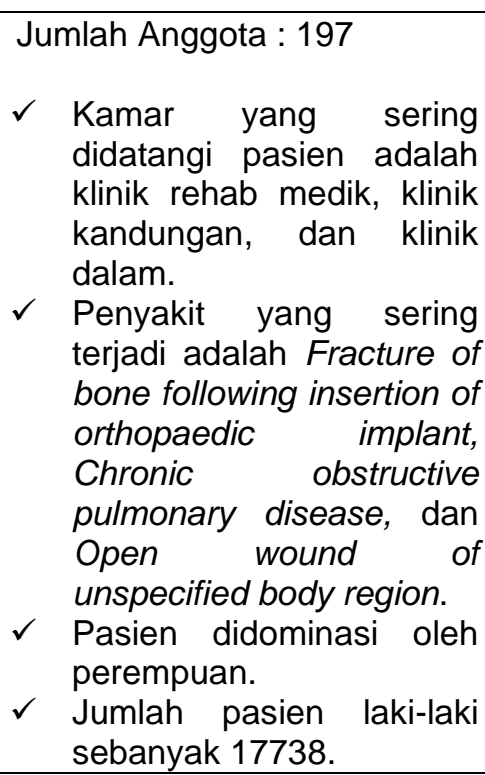 \\
\hline
\end{tabular}

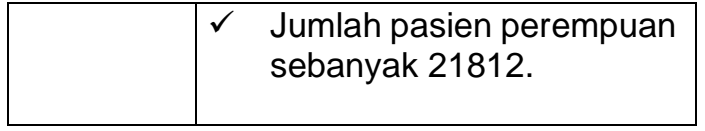

Hasil Penelitian pada klasterisasi data penyakit pasien di RSUD Kota Bandung dengan menggunakan Algoritma K-Medoids menunjukan bahwa cluster 2 menjadi cluster paling tinggi dengan jumlah penyakit 197 data, lalu disusul oleh cluster 0 dengan jumlah penyakit 18 data dan cluster 1 menjadi cluster terendah dengan jumlah penyakit 2 data. Angka tersebut menunjukan hasil yang sama baik dari perhitungan manual di Microsoft Excel maupun hasil dari Rapidminer.

Menimbang dari hasil penelitian yang telah dilakukan, diharapkan dengan adanya penelitian ini dapat memberikan informasi mengenai penyakit pasien yang sering terjadi berdasarkan kamar dan jumlah pasien, sehingga pihak rumah sakit dapat mengambil tindakan kebijakan dalam antisipasi pengobatan dan pencegahan penyakit. Selain itu, hasil penelitian ini dapat dijadikan sebagai bahan evaluasi pihak rumah sakit dalam merencanakan pembangunan fasilitas baru, penambahan tenaga medis spesialis ataupun penambahan jenis obat.

\section{Kesimpulan}

Berdasarkan hasil penelitian mengenai pengelompokan data penyakit pasien dengan menggunakan algoritma $K$ Medoids maka diperoleh beberapa kesimpulan sebagai berikut:

1. Pengelompokan penyakit pasien dengan atribut Kode ICD, Nama Penyakit, Kamar, Laki-laki dan Perempuan menggunakan algoritma $K$ Medoids dengan jumlah sampel sebanyak 217 data yang dibentuk menjadi 3 cluster menghasilkan hasil clustering dimana pada cluster 0 terdapat 18 data yang mana kamar yang sering didatangi pasien adalah klinik syaraf, klinik gawat darurat dan klinik dahlia dengan penyakit yang sering terjadi adalah Sequelae of stroke dan pasien didominasi oleh perempuan. Kemudian pada cluster 1 hanya terdapat 2 data yang mana kamar yang sering diatangi pasien adalah klinik kemuning dan klinik gawat darurat dengan penyakit yang sering terjadi adalah Fever dan HIV disease resulting in unspecified infectious or parasitic disease dan didominasi oleh pasien laki- 
laki. Sedangkan pada cluster 2 terdapat 197 data yang mana kamar yang sering didatangi pasien adalah klinik rehab medik, klinik kandungan, dan klinik dalam dengan penyakit yang sering terjadi adalah Fracture of bone following insertion of orthopaedic implant, Chronic obstructive pulmonary disease, dan Open wound of unspecified body region dan pasien didominasi oleh perempuan.

2. Berdasarkan nilai evaluasi Silhouette Coefficient pembentukan 3 cluster telah dinilai baik karena dengan percobaan evaluasi dari pembentukan jumlah $k$ (cluster) $2-5 k$ (cluster), jumlah $k$ (cluster) sama dengan 3 merupakan nilai yang paling mendekati 1 yaitu sebesar 0,409373.

3. Algoritma K-Medoids telah bekerja dengan baik karena setiap objek pada setiap cluster memiliki mutu yang baik, dimana setiap objek telah dikelompokan sesuai dengan tingkat kemiripan yang tinggi.

4. Dari hasil cluster didapat informasi tentang penyakit yang sering terjadi berdasarkan kamar dan jumlah pasien sehingga dapat membantu pihak rumah sakit untuk mengambil tindakan kebijakan dalam antisipasi pengobatan dan pencegahan penyakit. Selain itu, hasil penelitian ini dapat dijadikan sebagai bahan evaluasi pihak rumah sakit dalam merencanakan pembangunan fasilitas baru, penambahan tenaga medis spesialis ataupun penambahan jenis obat.

\section{Referensi}

Amrin, Satriadi, I., \& Rosanto, O. (2019). Algoritma C4.5 Untuk Diagnosa Penyakit Tuberkulosis. Jurnal Khatulistiwa Informatika, VII(2), 79-84.

Asmiatun, S., Wakhidah, N., \& Putri, A. N. (2020). Penerapan Metode K-Medoids Untuk Pengelompokkan Kondisi Jalan Di Kota Semarang 1,2. Jurnal Teknik Informatika Dan Sistem Informasi, 6(2), 171-180.

Juninda, T., Mustakim, \& Andri, E. (2019). Penerapan Algoritma K-Medoids untuk Pengelompokan Penyakit di Pekanbaru Riau. Seminar Nasional Teknologi Informasi Komunikasi Dan Industri (SNTIKI), November, 42-49.

Muningsih, E., \& Kiswati, S. (2015).
Penerapan Metode K-Means Untuk Clustering Produk Online Shop Dalam Penentuan Stok Barang. Jurnal Bianglala Informatika, 3(1). (17 Mei 2020)

Silitonga, P. D. P., \& Sri, I. (2017). Klusterisasi Pola Penyebaran Penyakit Pasien Berdasarkan Usia Pasien Dengan Menggunakan K-Means Clustering. Jurnal Times, VI(2), 20052008.

Sundari, S. S., \& Ariani, N. (2019). Penerapan Data Mining Untuk Pengelompokan Penyakit Dengan Algoritma Fuzzy C-Means ( Studi Kasus: UPT Puskesmas Salawu ). Jurnal VOI (Voice of Informatics), 8(2), 63-76.

Triyanto, W. A. (2015). Algoritma K-Medoids Untuk Penentuan Strategi Pemasaran. Jurnal SIMETRIS, 6(1), 183-188. 